\title{
Revista Brasileira de Fruticultura Ecological anatomy of Eugenia luschnathiana (O.Berg) Klotzsch ex B.D.Jacks. (Myrtaceae) leaves in the Restinga region, state of Ceara
}

\author{
Viviane de Oliveira Thomaz Lemos ${ }^{1}$, Eliseu Marlônio Pereira de Lucena ${ }^{2}$, Oriel Herrera Bonilla ${ }^{3}$, \\ Bruno Edson-Chaves ${ }^{4}$, Marina Arruda de Castro ${ }^{5}$, Valéria da Silva Sampaio ${ }^{6}$
}

\begin{abstract}
Eugenia luschnathiana (O.Berg) Klotzsch ex B.D.Jacks. (Myrtaceae) species, commonly known as pitomba-da-baía, occurs in Restinga region in the state of Ceara and has medicinal potential. The present study aimed to characterize the anatomy of E. luschnathiana leaves in the rainy and dry seasons, as well as in the sun and shade in the Restinga region of Ceara, aiming to generate useful information to understand the adaptive value of morphoanatomic responses to the natural conditions of occurrence of the species. Collections were performed at the State Botanical Park of Ceara, and leaves were completely expanded and fixed in FAA 70 , being replaced by $70 \%$ ethanol after $24 \mathrm{~h}$. Samples were submitted to standard plant anatomy methodologies in order to qualitatively and quantitatively analyze the leaf blade and petiole structures. As a result, there were differences among sun and shade leaves, rain and dry. In relation to luminosity, most determinations were higher in sun leaves: trichome density and frequency; trichome scar frequency; stomatal frequency, stomatal index, length, width and area of stomata; thickness of leaf blade, mesophyll, cuticle, epidermis, palisade and spongy parenchyma; length and width of the central vein, area of the central vein vascular bundle, number of secretory cavities in the central vein; length and width of the petiole, area of the petiole vascular bundle; amount and area of secretory cavities in the petiole. In shade leaves, only the number of druses in the central vein and petiole were larger. Regarding seasonality, all determinations were higher in the rainy season, except for the length and width of the central vein; number of druses in the central vein and petiole; length of the petiole, area of the vascular bundle and secretory cavities of the petiole. Therefore, it could be concluded that $E$. luschnathiana has great acclimative capacity to conditions of intense luminosity and periods of water deficit.
\end{abstract}

Index terms: Myrtaceae, pitomba-da-baía, anatomical plasticity, seasonality, luminosity.

\section{Anatomia ecológica foliar da Eugenia luschnathiana (O.Berg) Klotzsch ex B.D.Jacks. (Myrtaceae) na Restinga cearense}

\begin{abstract}
Corresponding author: viviane.7lemos@gmail.com
\end{abstract}

Received: September 25, 2017. Accepted: February 07, 2018.

Copyright: All the contents of this journal, except where otherwise noted, is licensed under a Creative Commons Attribution License.

(cc) $\mathrm{EY}$

Resumo - A espécie Eugenia luschnathiana (O.Berg) Klotzsch ex B.D.Jacks. (Myrtaceae), vulgarmente conhecida como pitomba-da-baía, ocorre em região de Restinga no Estado do Ceará e possui potencial medicinal. O presente estudo objetivou caracterizar a anatomia foliar da E. luschnathiana nas estações de chuva e seca, bem como ao sol e à sombra na Restinga cearense, visando a gerar informações úteis para a compreensão do valor aclimatativo das respostas morfoanatômicas às condições naturais de ocorrência da espécie. Foram realizadas coletas, no Parque Estadual Botânico do Ceará, de folhas completamente expandidas e fixadas em FAA70, sendo substituído por etanol a 70\%, após $24 \mathrm{~h}$. As amostras foram submetidas a metodologias-padrão em anatomia vegetal, a fim de analisar qualitativa e quantitativamente as estruturas da lâmina foliar e do pecíolo. Como resultado, verificaram-se diferenças entre folhas de sol e sombra na chuva e na seca. Em relação à luminosidade, a maioria das determinações foi maior nas folhas de sol: densidade e frequência de tricomas; frequência de cicatriz de tricomas; frequência estomática, índice estomático, comprimento, largura e área dos estômatos; espessura da lâmina foliar, mesófilo, cutícula, epiderme, parênquima paliçádico e esponjoso; comprimento e largura da nervura central, área do feixe vascular da nervura central, quantidade de cavidades secretoras na nervura central; comprimento e largura do pecíolo, área do feixe vascular do pecíolo, quantidade e área de cavidades secretoras no pecíolo. Nas folhas de sombra, apenas a quantidade de drusas na nervura central e no pecíolo foram maiores. Em relação à sazonalidade, todas as determinações foi maior na estação de chuva, com exceção do comprimento e da largura da nervura central; quantidade de drusas na nervura central e no pecíolo, comprimento do pecíolo, área do feixe vascular e das cavidades secretoras do pecíolo. Portanto, conclui-se que a E. luschnathiana possui grande capacidade aclimatativa às condições de intensa luminosidade e períodos de déficit hídrico.

Termos para indexação: Myrtaceae, pitomba-da-baía, plasticidade anatômica, sazonalidade, luminosidade.

\footnotetext{
${ }^{1}$ Master in Natural Resources, State University of Ceara-UECE, Av. Dr. Silas Munguba, 1700, Itaperi Campus, CEP 60.714-903, Fortaleza-CE, Brazil. E-mail: viviane.7lemos@gmail.com

${ }^{2} \mathrm{PhD}$ in Agronomy, Associate Professor of the Biological Sciences Course, CCS/UECE, Fortaleza-CE, Brazil. E-mail: eliseu.lucena@uece.br ${ }^{3} \mathrm{PhD}$ in Ecology, Associate Professor of the Biological Sciences Course, CCS/UECE, Fortaleza-CE, Brazil. E-mail: oriel.herrera@uece.br ${ }^{4}$ Master in Botany, Assistant Professor of the Biological Sciences Course, FECLI/UECE, Iguatu-CE, Brazil. E-mail: bruno.edson@uece.br ${ }^{5}$ Bachelor in Biological Sciences, CCS/UECE, Fortaleza-CE, Brazil. E-mail: marinacastro1206@gmail.com ${ }^{6} \mathrm{PhD}$ student in Ecology and Natural Resources, CC/UFC, Fortaleza-CE, Brazil. E-mail: valeriasampabiobio@gmail.com
} 


\section{Introduction}

Myrtaceae is a widely studied species due to its chemical characteristics of medicinal potential and to the presence of secondary metabolites (ALVARENDA et al., 2015; OLIVEIRA et al., 2016b; SIMONETTI et al., 2016). The great diversity of this family is reflected in the Restinga regions of Brazil (LOURENÇO; BARBOSA, 2012), being well representative in São Gonçalo do Amarante, Ceara (CASTRO et al., 2012). One of the most representative genera of the family is Eugenia L., with about 387 species occurring in Brazil (BFG, 2015). One of the species rarely studied in this group, mainly in relation to the leaf anatomy is Eugenia luschnathiana (O.Berg) Klotzsch ex B.D. Jacks., Popularly known as pitomba-da-baía (LUCENA et al., 2014).

E. luschnathiana has great pharmacological value because it has phenolic compounds and anthocyanins of important dietary antioxidant effect (REYNERTSON et al., 2008). It is a native fruit of Brazil and can be found in the nature as shrubs or small trees, differing of the other Eugenia species because its leaves have primary venation adaxially concave, raceme with indefinite primary axis finished in vegetative branch, pyloric stem disc, hairy stylet and globoid to subgloboid fruits (AMORIM; ALVES, 2012). Although E. luschnathiana has low importance value index $(\mathrm{IVI}=0.61)$ in the coast sampled in Pecém, São Gonçalo do Amarante-CE (CASTRO et al., 2012), it plays an important ecological role in the Restinga region of Ceara, because it attracts different pollinators, seed dispersers and herbivores, among which are insects, frugivorous birds, bats and monkeys.

Leaves have great ecological plasticity, promptly acclimating to environmental variations (SULTAN, 2000; VALLADARES et al., 2000; SULTAN, 2003). Abiotic conditions such as luminosity and water availability can influence the anatomical structure of plants for a better acclimatization to the environment which they are inserted (PACHECO-SILVA; DONATO, 2016; OLIVEIRA et al., 2016b).

Some characteristics such as stomata can be reported as an example in ecological plasticity, since depending on the species, the quantity may be higher or lower, under conditions of high luminosity and water scarcity (DONATO; MORRETES, 2009; VILE et al., 2012; OLIVEIRA et al., 2016a). Other examples that undergo modifications in the aforementioned conditions are the greater thickness of the cuticle on the adaxial face and numerous trichomes on the abaxial side (ESPOSITOPOLESI et al., 2011). In relation to luminosity, it is possible to mention, among others, greater thicknesses of the leaf blade and palisade parenchyma in leaves collected in the sun, which can increase the photosynthetic potential (EVERT, 2013; AMORIM; MELO JÚNIOR, 2017). It was also observed that the greater thickness of the spongy parenchyma also increases the photosynthetic rate due to the existence of more chloroplasts in the mesophyll (OGUCHI et al., 2006, HIKOSAKA et al., 2014).

The ecological anatomy study is important to explain the acclimative strategies of plants to survive in the diverse environmental conditions in their habitat. Therefore, the hypothesis of the present work was that there is a correlation between the anatomy of Eugenia luschnathiana (O.Berg) Klotzsch ex B.D. Jacks leaves and the environmental conditions to which they are exposed.

Therefore, the aim of the present work was to characterize the anatomy of Eugenia luschnathiana (O.Berg) Klotzsch ex B.D. Jacks leaves in rainy and dry seasons, as well as, in the sun and shade in the Restinga region of the state of Ceara, aiming to generate useful information to understand the acclimative value of the morphoanatomic responses to the natural conditions of occurrence of the species.

\section{Material and methods}

E. luschnathiana branches were collected in a Restinga area of the Vegetation Complex of the State Botanical Park of Ceara Coastal Zone ( $3^{\circ} 42^{\prime} 45.8^{\prime \prime} \mathrm{S}$ and $38^{\circ} 38^{\prime} 29.6^{\prime \prime} \mathrm{W}$ and $21 \mathrm{~m}$ a.s.1.), in Caucaia-CE, which consists of Restinga, Caatinga and Mangrove, with average temperature of $26-28^{\circ} \mathrm{C}$, average annual rainfall of $1,243.2 \mathrm{~mm}$, with rainy months from January to May and the driest months from August to October (IPECE, 2018), with equatorial Savannah climate and dry summer (As), according to the Köppen climatic classification (ALVARES et al., 2013).

For the anatomical study, completely expanded leaves located on the $3^{\text {rd }}$ to $5^{\text {th }}$ node of branches were collected, fixed at FAA70 (JOHANSEN, 1940) and after 24 hours preserved in 70\% ethanol (JENSEN, 1962), remaining immersed in this solution until later stages at the Laboratory of Ecology, State University of Ceara. In the field, temperature and humidity were also measured using the J-Prolab thermo-hygrometer apparatus.

Plant samples were obtained from ten different individuals in the Restinga Forest, five located at the border of the forest (sun plants - average temperature of $36.41^{\circ} \mathrm{C}$ and average relative humidity of $50.2 \%$ ) and five located within the forest with dense vegetation (shade plants - average temperature of $35.63^{\circ} \mathrm{C}$ and average relative humidity of $53.2 \%$ ), both collections were carried out in the rainy season (April) and in the dry season (October) of 2016, for seasonal ecological comparison. According to FUNCEME (2018), the annual precipitation in Caucaia-CE in the year of collection (2016) was 1,206 $\mathrm{mm}$, with minimum rainfall in October and November (3.4 $\mathrm{mm}$ ) and maximum rainfall in March and April (287.9 and $277.9 \mathrm{~mm}$, respectively).

Samples were cut in the cross-sectional direction in 
the middle third, border and central vein of the leaf blade, in addition to petiole section, made by free hand using Ranvier's microtome. This was followed by clarification in 20-30\% sodium hypochlorite and washing 3-6 times with distilled water (KRAUS; ARDUIM, 1997), followed by alcian blue/safranin (4:1) staining (LUQUE et al., 1996). Subsequently, the material was dehydrated in a growing ethylic series, passing through butyl acetate and mounted on glass varnish (PAIVA et al., 2006).

For analysis of the epidermis, portions of materials were submitted to Franklin solution (1945) (at 1:1 concentration, with change in the hydrogen peroxide, used at $60 \%$ ) for 24 hours in an oven at $80^{\circ} \mathrm{C}$. Parasidermic samples were stained with alcoholic safranin (JOHANSEN, 1940), washed in distilled water, dehydrated in ethyl series, passed through butyl acetate and mounted on glass varnish (PAIVA et al., 2006).

For photographic recording, a DSC-W530 camera coupled to BEL PHOTONICS optical microscope was used. For the measurements of anatomical structures, the Image-Pro Plus software was used.

For the cross sections in the median third region, the total thickness of the leaf blade, adaxial and abaxial cuticle, adaxial and abaxial epidermis, mesophyll, palisade and spongy parenchyma was quantitatively evaluated $(\mathrm{n}=$ 30). In the median region of the central vein, its length and total width, area of the central vascular bundle, as well as, number of druses and secretory cavities were measured. The same parameters were also measured in the petiole, plus the area of secretory cavities.

In paradermal sections, the density (number of analyzed structures/area) and relative frequency (number of structures analyzed/total epidermal cells) of trichomes, trichome scars and stomata were quantitatively examined $(\mathrm{n}=30)$. Length, width and area of each stoma were also measured in the Image-Pro Plus software, as well as the stomatal index based on formula adapted by Willmer and Fricker (1996).

The experimental design was completely randomized, with $2 \times 2$ factorial (rain and dry) $\mathrm{x}$ (sun and shade) and 30 replicates. The results were submitted to the normality test, followed by analysis of variance observing the significance by the F test and when significant, the Tukey test was carried out at $5 \%$ probability level (SANTOS et al., 2008). The $t$ test at $1 \%$ probability level was also performed for the thicknesses of cuticle and epidermis (VIEIRA, 2011).

\section{Results}

\section{Qualitative analyses}

The adaxial face of the epidermis of E. luschnathiana sun leaves presented cells with straight anticlinal walls (Figures 1A and 1C), while shade leaves were slightly sinuous in the rainy season (Figure 1B) and markedly sinuous in the dry season (Figure 1D). In this region, the epidermal cell of the secretory structure surrounded by polygonal cells to circular cells arranged in radiated form could be observed (Figure 1A).

The epidermal cells common of the abaxial face resembled that of the adaxial face; however, showing paractic trichomes and stomata (Figures $1 \mathrm{E}-\mathrm{H}$ and $1 \mathrm{~J}$ ). The trichomes that were found were of the unicellular tectorial type, which presented great quantity (Figures $1 \mathrm{E}$ and $1 \mathrm{G})$; therefore, the presence of trichome scars was frequent (Figures $1 \mathrm{E}-\mathrm{H}$ and $1 \mathrm{~K}$ ). The presence of the epidermal cell of the secretory structure involved by cells similar to those described for the adaxial face could be observed (Figures 1F, 1H and 1I).

The epidermis of both faces was uniestratified, with thick cuticle (Figures 2A-E). Stomata were found on the same level as the other common epidermal cells (Figure 2B).

The cross section of the E. luschnathiana leaf blade revealed typical dorsiventral structure (Figures 2A-E), with uniestratified palisade parenchyma.

The spongy parenchyma had 7-10 cell strata, which delimited wide intercellular spaces (Figures 2A-E) and contained collecting cells, involving the vascular bundles (Figures 2A and 2E). In the spongy parenchyma, there are small vascular bundles, surrounded by parenchymal sheath and fibers occurring in both poles of the bundles (Figures 2A-E). The spongy parenchyma also presented idioblasts with druses (Figures 2A and 2D-E).

It was possible to verify the presence of secretory structures, of the secretory cavity type, with large rounded cavity delimited by secretory cells and with cells that project to the epidermis. The distribution of these structures is diffuse, which are located on the adaxial and abaxial face of the leaf. The secretory structures presented diameter that exceeds the height of cells of the palisade parenchyma, reaching the spongy parenchyma (Figure 2C).

In general, the foliar border region was rectilinear (Figures 2H-K). However, sun leaves could also present it slightly flexed towards the abaxial face (Figures 2F$\mathrm{G})$. The presence of collenchyma was observed on the border, and in this region, the palisade parenchyma was interrupted and the spongy parenchyma was reduced to about four cell layers (Figure $2 \mathrm{H}$ and $2 \mathrm{~L}$ ). Near the border, a vascular bundle occurred, with a small number of conductive elements and presence of fibers (Figures $2 \mathrm{H}$ and $2 \mathrm{~L}$ ).

The median vein region, in cross section, was concave-convex (Figures 3A-D). On the adaxial face, the palisade parenchyma was usually interrupted by $8-10$ colenchymatic cells, which made contact with the fibers that enveloped the vascular bundle (Figures 3A and 3CD). The bicolateral vascular bundle organized in an arch was found facing the adaxial face (Figures 3A-D). In the 
abaxial face, 6-8 parenchyma and 1-2 colenchyma layers occurred in contact with epidermal cells (Figures 3A-D). In the central vein, it was possible to verify the presence of secretory cavities and idioblasts with druses (Figure 3C).

The median region of the petiole in cross section was flat-convex (Figures 3E-G) to concave-convex (Figure 3). The epidermis was uniestratified, with rare unicellular tectorial trichomes (Figures 3E-I). In the region below the epidermis, 2-3 colenchyma layers occurred (Figures
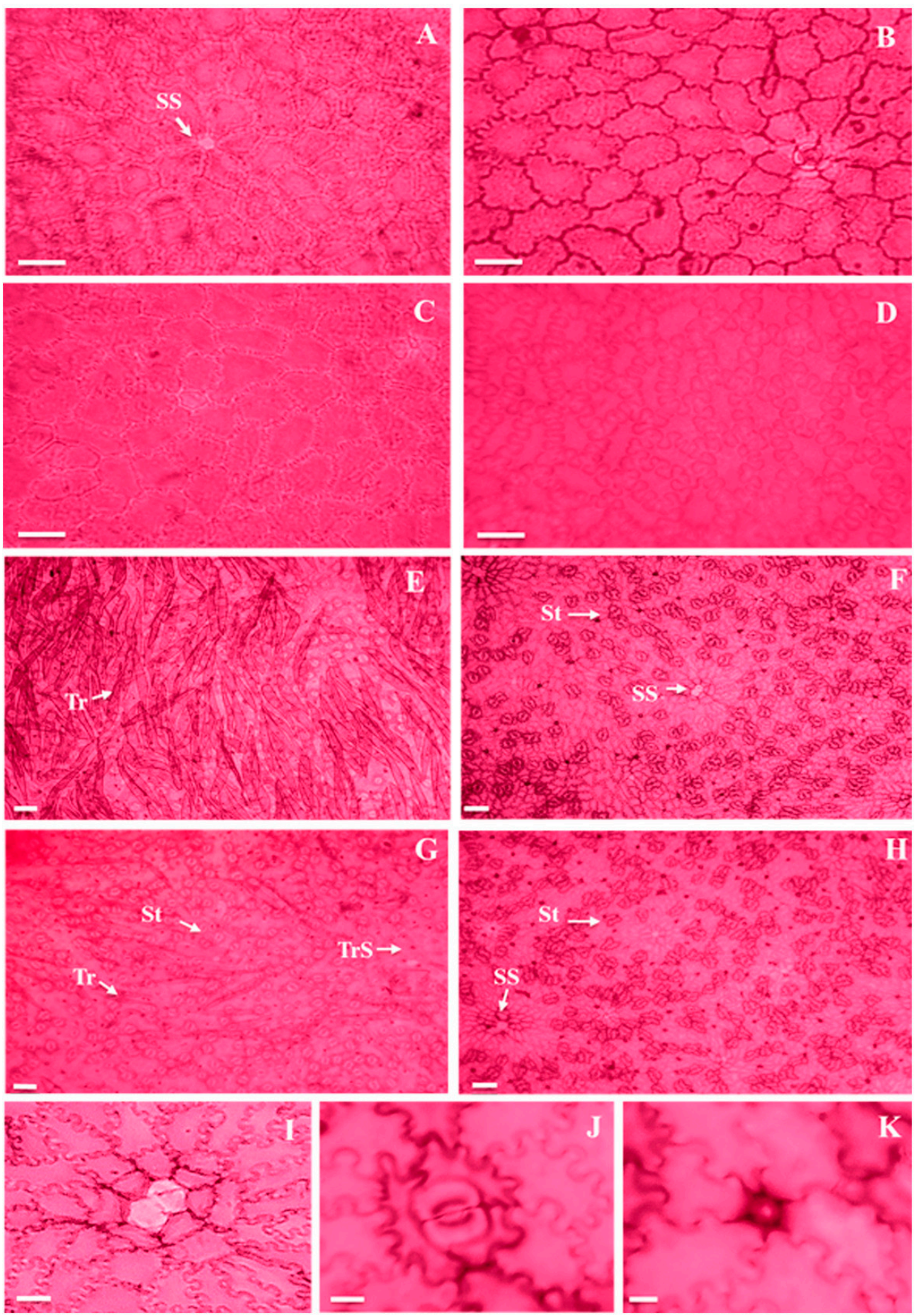

Figure 1 - Adaxial (A-D) and abaxial epidermis (E-H) of Eugenia luschnathiana leaves (O.Berg) Klotzsch ex B.D.Jacks. in front view. Treatments: A and E- rain/sun; B and F- rain/shade; C and G- dry/sun; D and H- dry/ shade. Expanded structures: I- epidermal cells of the secretory structure; J- paracytic stomata; K- trichome scar. Abbreviations: TrS- trichome scar; SS- secretory structure; St- stomata; Tr- trichome. Bar: 30 (A-H) and 5 (I-K) $\mu \mathrm{m}$. 

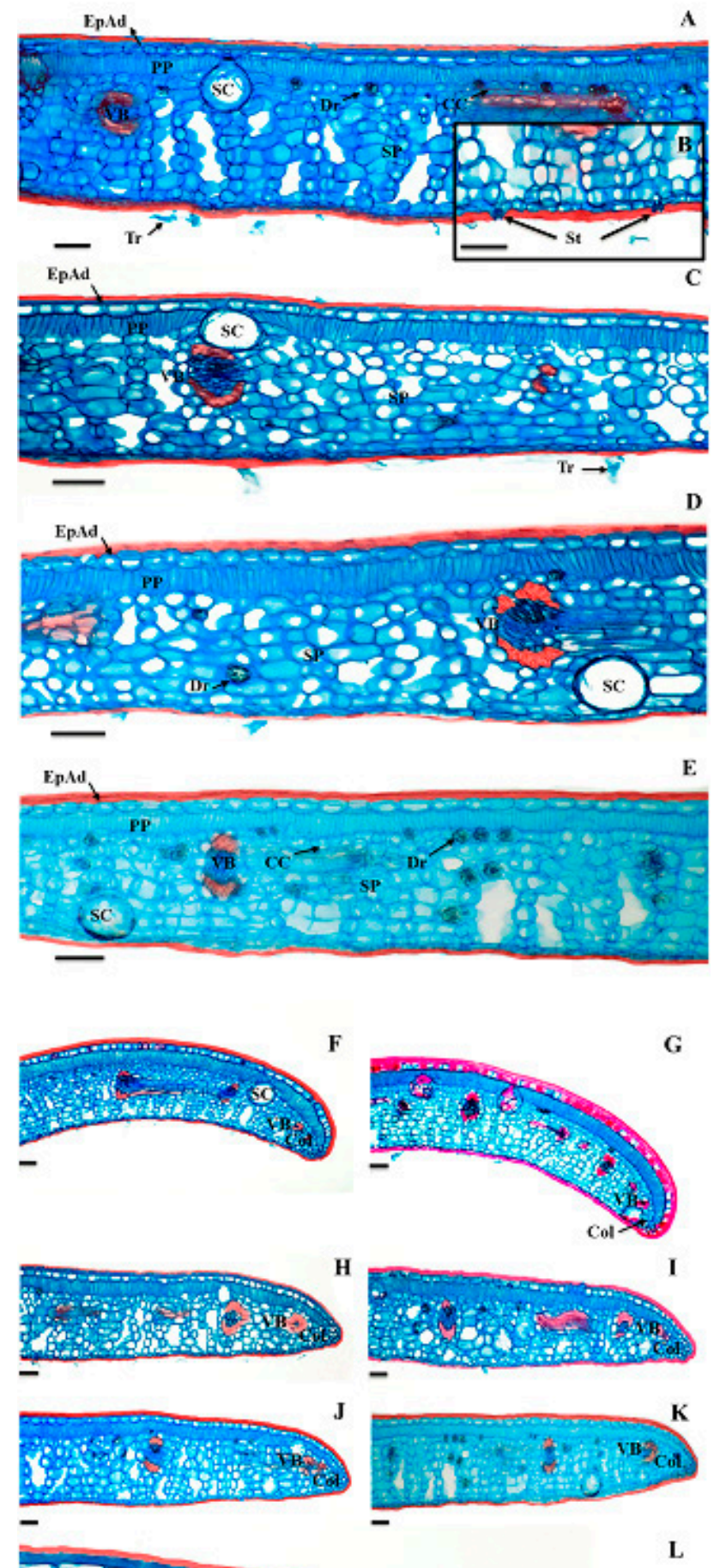

Figure 2 - Cross section (A-E) and leaf border (F-L) of Eugenia luschnathiana leaves (O.Berg) Klotzsch ex B.D. Jacks. Treatments: A- rain/sun; B- detail showing stomata; C- rain/shade; D- dry/sun; E dry/shade; F- rain/sun slightly flexed to the abaxial face; G- dry/sun slightly flexed to the abaxial face; H- rain/sun rectilinear; I- dry/sun rectilinear; J- rain/shade rectilinear; K- dry/shade rectilinear; L- Figure H magnified. Abbreviations: CC- collection cells; Colcolenchyma; SC- secretory cavity; Dr- druses; EpAd- epidermis adaxial; St- stomata; VB- vascular bundle; SPspongy parenchyma; PP- palisade parenchyma; Tr- unicellular tectorial trichome. Bar: 60 (A-L) $\mu \mathrm{m}$. 

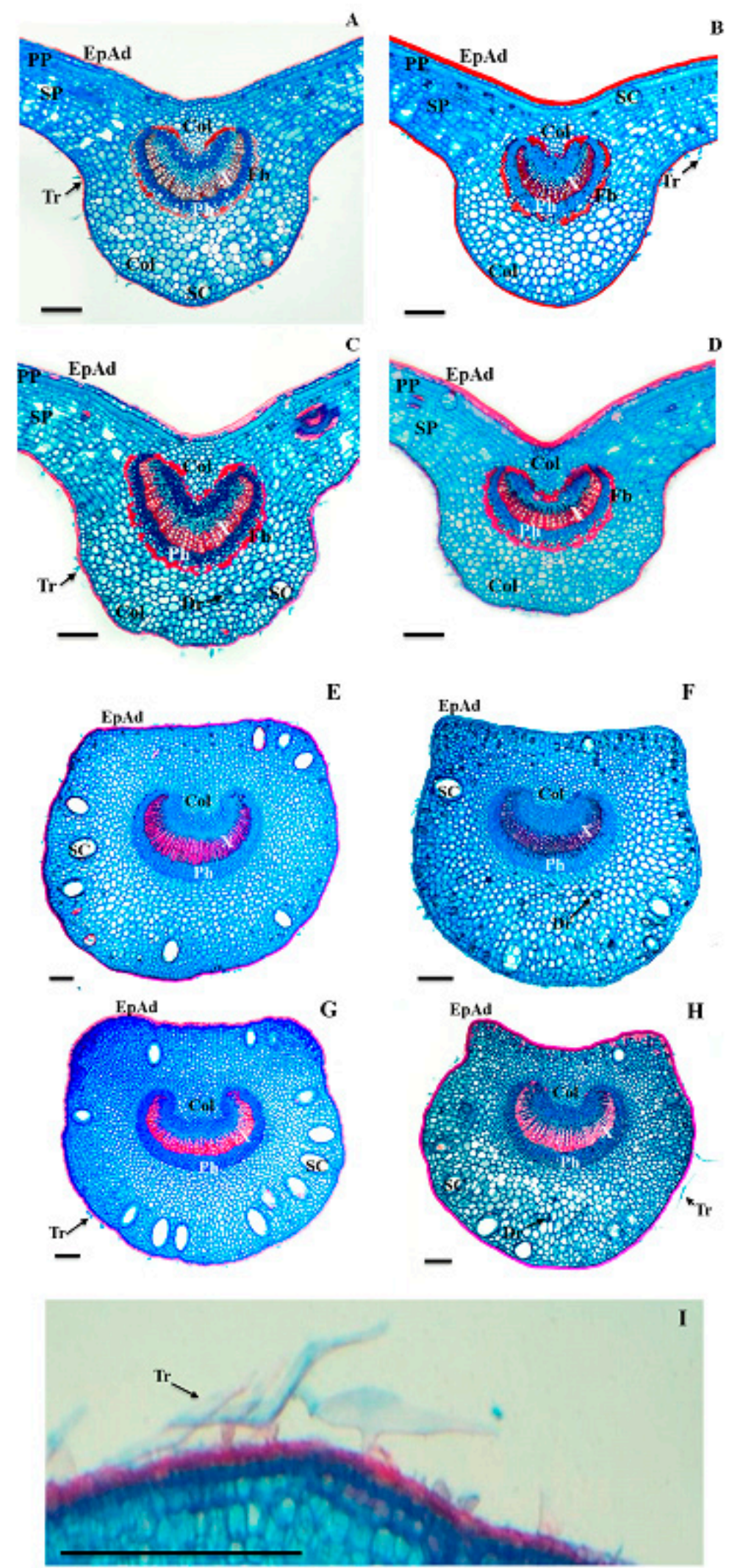

Figure 3- Median vein (A-D) and petiole (E-I), in cross-section of Eugenia luschnathiana (O.Berg) Klotzsch ex B.D. Jacks. Treatments: A and E- rain/sun; B and F- rain/shade; C and G- dry/sun; D and H- dry/shade. Expanded structure: I- petiole with trichomes. Abbreviations: Col- colenchyma; SC- secretory cavity; Dr- druses; EAd- epidermis adaxial; Fb- fibers; Ph- phloem; SP- spongy parenchyma; PP- palisade parenchyma; Tr- trichome; X- xylem. Bar: 160 (A-I) $\mu \mathrm{m}$. 


\section{Quantitative analyses}

Quantitative analysis was performed for the abaxial face of the leaf, since this region shows structures of interest for the statistical comparison.

Trichomes showed higher density in sun leaves in both seasons (Figures 1E and 1G); however, no difference was observed in the seasonal comparison. On the other hand, the frequency of trichomes was higher in the rainy season and in sun leaves in both seasons. Trichome scars did not reveal statistical differences among treatments as to their density, although there was interaction among them. However, their frequency was significant in relation to luminosity, being higher in sun leaves (Table 1).

Density and stomatal frequency exhibited differences between seasons, presenting higher values in the rainy season. However, in terms of luminosity, only frequency showed significant change, being higher in sun leaves. The stomatal index was higher in the rainy season and in sun leaves. Length, width and area of stomata presented significant differences only in luminosity, being higher in sun leaves, with interaction occurring only among treatments for length (Table 1).

The thickness of epidermis and adaxial cuticle presented significant differences in luminosity, being thicker in sun leaves, in which only epidermis presented interaction among treatments. The cuticle also differed statistically regarding seasonality, being thicker in the rainy season. The epidermis and abaxial cuticle presented differences only in luminosity, being thicker in sun leaves, with interaction among treatments. Both epidermis and abaxial cuticle were less thick than the adaxial face, and were confirmed by the t-test at $1 \%$ probability level (Table 2).

The leaf blade and leaf mesophyll showed higher thickness in sun leaves, but did not present statistical difference regarding seasonality; however, there was interaction among treatments, in which thickness was higher in the rain/sun treatment (Table 2). The palisade parenchyma and the spongy parenchyma presented statistical differences regarding luminosity, being thicker in sun leaves; however, only the palisade parenchyma showed interaction among treatments and differed statistically regarding seasonality, being thicker in the rainy season (Table 2).

The length and width of the central vein showed statistical differences in relation to seasonality and luminosity, being higher in leaves collected in the dry season and in the sun, in both seasons (Table 2). However, there was no interaction among treatments. The area of the vascular bundle differed only in relation to luminosity, being greater in sun leaves, with interaction among treatments (Table 2). The secretory cavities present in the central vein presented differences only regarding luminosity and appeared in greater amounts in sun leaves (Table 2). Druses were more abundant in leaves collected in the dry season, both in sun and shade leaves, although in shade leaves, the amount verified was higher in both seasons. Interaction among treatments was also observed (Table 2).

Petiole length differed statistically in relation to seasonality and luminosity, which showed longer length in the dry season and in sun leaves in both seasons, but no interaction among treatments was observed (Table 2). Width was influenced only by luminosity, being higher in sun leaves and there was interaction among treatments, with the greatest width observed in the dry/sun (Table 2). The area of the vascular bundle differentiated in relation to seasonality and luminosity, showing greater thickness in the dry season and in sun leaves in both seasons, with interaction among treatments, and the dry/sun showed the greatest area of the vascular bundle (Table 2). The secretory cavities found in the petiole presented larger area and greater amount of sun leaves in the dry season (Table 2). In relation to idioblasts containing crystals in the petiole, greater amount was detected in the dry season and in shade leaves in both seasons (Table 2).

\section{Discussion}

\section{Qualitative characteristics}

Eugenia luschnathiana presented features common to Myrtaceae, such as unicellular trichomes, hyposomatic leaf, occurrence of secretory cavities, bicolateral vascular bundle and presence of druses (METCALFE; CHALK, 1979).

As for the coating system, some similarities can be observed with studies carried out with other Eugenia L. species such as presence of thick cuticle, hypoestomatic leaf (DEFAVERI et al., 2011; DONATO; MORRETES, 2009; ESPOSITO-POLESI et al., 2011; DIAS et al., 2012; SÁ et al., 2016), unicellular tectorial trichomes, presence of trichome scars (DEFAVERI et al., 2011; DONATO; MORRETES, 2009; ESPOSITO-POLESI et al., 2011) and occurrence of epidermal cells of secretory structure surrounded by cells arranged in a radiated form (DEFAVERI et al., 2011; DONATO; MORRETES, 2009; DIAS et al., 2012; SÁ et al., 2016).

The study carried out by Donato and Morretes (2009) with E. florida DC species showed that the cells of the epidermis presented sinuous shape, especially in sun leaves; however, species in the present study presented greater sinuosity in shade leaves. Walls present sinuous shape, probably due to tensions in leaves during cell differentiation or cuticle hardening during differentiation (MENEZES et al., 2006).

Uniseriate epidermis was also found in other Eugenia species (ESPOSITO-POLESI et al., 2011; DONATO; MORRETES, 2009; DIAS et al., 2012; SÁ et al., 2016; DEFAVERI et al., 2011). Stomata on the same level as the other epidermal cells common in $E$. 
luschnathiana corroborate data found by Armstrong et al. (2012).

Hypoestomatic leaves also appear in other Myrtaceae (CUSTÓIO et al., 2013; DONATO; MORRETES, 2011; PACHECO-SILVA; DONATO, 2016; RETAMALES et al., 2014; SILVA et al., 2013). This characteristic can favor plants that live in environments with high luminosity and periods of water deficit, enabling saving water because it reduces transpiration rates (ESPOSITO-POLESI et al., 2011).

Myrtaceae presents different types of stomatal complexes, usually presenting stomatal cells at the same level of the epidermis (GOMES et al., 2009), as observed in this study. The species under study has paracytic stomata, being also common in other species of the genus the paracytic (DONATO; MORRETES, 2009), anomocytic stomata (DEFAVERI et al., 2011) or both types mentioned above (DIAS et al., 2012; SÁ et al., 2016).

Dorsiventral mesophyll with a single palisade parenchyma layer and presence of collecting cells were also found for E. florida DC. (DONATO; MORRETES, 2009), as well as in other Myrtaceae species (PACHECOSILVA; DONATO, 2016; RETAMALES et al., 2014; SILVA et al., 2013; DONATO; MORRETES, 2011).

The spongy parenchyma shows large intercellular spaces, vascular bundles of smaller caliber and presence of druses, as it was detected for other species of the same genus (DONATO; MORRETES, 2009; ESPOSITOPOLESI et al., 2011). In this type of parenchyma, the shape of cells favors the absorption of carbon dioxide for photosynthesis (MENEZES et al., 2006). This parenchyma also shows druses, which can act in the protection of foliar tissue against herbivorous attacks, calcium regulation, detoxification, ionic balance, support, tissue stiffness and uniformly reflect the solar radiation among mesophyll cells (LARCHER, 2001; FRANCESCHI; NAKATA, 2005; FERREIRA et al., 2015).

The characterization of the leaf border seen by Donato and Morretes (2009) for E. florida species varies from rectilinear in sun leaves to slightly flexed in shade leaves, the opposite occurring for E. luschnathiana in the present study, in which the leaf border varies from rectilinear in sun and shade leaves to flexed towards the abaxial face in sun leaves. In E. rotundifolia (Arn.) Wight, the border region only appears flexed to the abaxial face (DEFAVERI et al., 2011).

In a study by Cardoso et al. (2009), it was observed that 44 Myrtaceae species presented bicolateral vascular bundles, as verified for E. luschnathiana in the present study. This characteristic has also been detected for other species of the genus (DONATO; MORRETES, 2009; DEFAVERI et al., 2011; ESPOSITO-POLESI et al., 2011; SÁ et al., 2016).

The vascular bundle of the median vein when associated with arch-shaped fibers provides greater resistance to the structure (ESPOSITO-POLESI et al., 2011). This characteristic is also present for other Eugenia L. species (ESPOSITO-POLESI et al., 2011; DONATO; MORRETES, 2009; DEFAVERI et al., 2011). The presence of sclerenchyma facilitates the filtering of light by increasing the light availability used in the photosynthesis of the innermost mesophyll layers (SIMIONI et al., 2017).

The cross-section of the medial region of the petiole of species under study can be presented in the plane-convex to concave-convex format, the latter being characteristic of other species of the genus. In addition, arch-shaped vascular bundle is common in Eugenia L., and margins are more convoluted than in the median vein; present secretory cavities near the colenchymal area and druses (DONATO; MORRETES, 2009; ESPOSITOPOLESI et al., 2011).

Secretory cavities such as those found in the present study had already been described for Myrtaceae by Metcalfe and Chalk (1979). These structures may be related to responses to the metabolism of chemicals and interactions between plant and the environment (RETAMALES et al., 2014).

\section{Quantitative characteristics}

The behavior of stomata is directly related to abiotic conditions (LARCHER, 2001). These structures vary in quantity, frequency, size, shape and distribution in leaves, favoring the mechanisms of adaptation of plants to these environments (SUTCLIFFE, 1980; WILLMER; FRICKER, 1996). One of these abiotic factors that can cause changes in stomata is the water deficit, because with stomatal closure, it is expected that gas exchanges carried out by plants will be affected and the organism will have to seek survival strategies (ALMEIDA et al., 2015). Another factor that provides different stress to leaves is luminosity and their morphophysiological responses to light, which vary according to type, either sun or shade leaves (NIINEMETS, 2007).

The stomatal index is practically constant for each species, being mainly affected by moisture (CUTTER, 1986). The highest stomatal index is advantageous in the rainy season, as it increases the stomatal conductance, transpiratory and photosynthetic rate (SILVA et al., 2005), helping plants to produce substances necessary for their survival more quickly. This factor can also vary with the intensity of light received by the plant, being greater the greater the luminosity received, thus helping to increase the $\mathrm{CO}_{2}$ concentration and to improve photosynthesis (SCHOCH et al., 1980; O'CARRIGAN et al., 2014).

Stomatal density varies according to several factors, including within the same species, being influenced by environmental conditions, mainly by water availability and temperature, being able to be higher at high temperatures and water deficit conditions. In this case, high stomatal 
density can help increase control over water loss and carbon dioxide absorption rates. On the other hand, low stomatal density under the same conditions mentioned above may contribute to the reduction of excessive transpiration; therefore, leaves can also be expected to present lower stomatal density in environments of water scarcity and high temperature (VILE et al., 2012, OLIVEIRA et al., 2016a), which may explain the stomatal density of the present study in the dry season.

Plants found in the same place theoretically are subject to the same pluviometric and edaphic conditions. Therefore, the main abiotic determinant is light intensity (LARCHER; BOEGER, 2009). The study by Donato and Morretes (2009) with Eugenia species found that the stomatal density was higher in leaves collected in the sun. Boeger et al. (2009) found that for four species of medicinal plants, the stomatal density was also higher in sun leaves. However in the present study, there was no statistical difference regarding the stomatal density in the luminosity.

The thick cuticle on the adaxial face and trichomes on the abaxial face may be characteristic of plants adapted to xeric environments, since they are highly irradiated and subject to periods of water deficit (ESPOSITO-POLESI et al., 2011). The thick cuticle can help to avoid excessive water loss by transpiration and also provides protection against high luminosity, as it may reflect excess sunlight (ESAU, 1977; MULLER; RIEDERER, 2005). In a study with Eugenia species, Donato and Morretes (2009) verified that the cuticle thickness was higher in leaves collected in the sun, as occurred for the present study.

Trichomes also prevent water loss because they reduce transpiration by reflecting excess sunlight. It also promotes an increase in the leaf surface layer, which can help attenuate ultraviolet solar rays, thus protecting the leaf tissue and decreasing its temperature (KARABOURNIOTIS; BORNMAN, 1999; EVERT, 2013). These structures can also increase the photosynthesis efficiency, allowing a better functioning of photosystem II and protection against herbivorous (MORALES et al., 2002; SATO; KUDOH, 2017). The higher density and frequency of trichomes obtained in leaves of this study corroborates the authors mentioned above.

The leaf blade presented greater thickness in sun leaves, corroborating the results obtained by Boeger et al (2009). Individuals more exposed to light radiation have thicker palisade parenchyma (AMORIM; MELO JÚNIOR, 2017). Palisade parenchyma undergoes modification according to the luminous intensity and is thicker as the light exposure is greater, accentuating the photosynthetic potential of sun leaves (RABELO et al., 2013, EVERT, 2013; TAIZ; ZEIGER, 2013). In addition, palisade parenchyma helps to distribute light more evenly to chloroplasts within the leaf, especially collimated light, which naturally spreads more slowly (VOGELMANN;
MARTIN, 1993).

In the present work, the spongy parenchyma was thicker in sun leaves; however, according to DeLucia et al. (1996), this structure can be affected in terms of luminosity, being thicker in shade leaves in order to increase the internal light dispersion, thus promoting better absorption of this light for photosynthesis.

Druses present in the spongy parenchyma may act in the uniform reflection of sunlight among mesophyll cells, which may explain the fact that in the present work, shade leaves have greater number of druses (LARCHER, 2001; FRANCESCHI; NAKATA, 2005; FERREIRA et al., 2015).

Leaf is the plant organ that is regarded as the one that most readily responds to environmental variations (EVERT, 2013). Abiotic conditions such as water deficit and light intensity induce xeromorphism (AMORIM; MELO JÚNIOR, 2017). Anatomically, xeromorphic characteristics are represented, among others, by the increased cuticle, larger vascular area, presence of numerous trichomes and fibers (MENEZES et al., 2006), as occurred for the species under study. 
Table 1 - Quantitative parameters of trichomes, trichome scars and stomata of the abaxial face of the epidermis of Eugenia luschnathiana (O.Berg) Klotzsch ex B.D.Jacks. leaves in the rainy and dry seasons, as well as in the sun and shade.

\begin{tabular}{lcccc}
\hline & \multicolumn{3}{c}{ Season } \\
\cline { 2 - 5 } Parameter & \multicolumn{2}{c}{ Rain } & \multicolumn{2}{c}{ Dry } \\
\cline { 2 - 5 } & \multicolumn{2}{c}{ Luminosity } & Suminosity \\
\cline { 2 - 5 } & $16.83 \pm 12.56 \mathrm{Aa}$ & $9.00 \pm 10.70 \mathrm{Ab}$ & $13.83 \pm 14.54 \mathrm{Aa}$ & $5.16 \pm 8.25 \mathrm{Ab}$ \\
Trichome density & $0.08 \pm 0.06 \mathrm{Aa}$ & $0.04 \pm 0.04 \mathrm{Ab}$ & $0.05 \pm 0.06 \mathrm{Ba}$ & $0.02 \pm 0.03 \mathrm{Bb}$ \\
Trichome frequency & $18.16 \pm 9.51 \mathrm{Aa}$ & $12.50 \pm 5.04 \mathrm{Aa}$ & $12.66 \pm 7.62 \mathrm{Aa}$ & $14.67 \pm 5.56 \mathrm{Aa}$ \\
Trichome scar density* & $0.09 \pm 0.05 \mathrm{Aa}$ & $0.06 \pm 0.01 \mathrm{Ab}$ & $0.07 \pm 0.06 \mathrm{Aa}$ & $0.06 \pm 0.03 \mathrm{Ab}$ \\
Trichome scar frequency & $34.63 \pm 8.94 \mathrm{Aa}$ & $33.63 \pm 7.84 \mathrm{Aa}$ & $31.50 \pm 8.62 \mathrm{Ba}$ & $28.00 \pm 8.05 \mathrm{Ba}$ \\
Stomatal density & $0.16 \pm 0.05 \mathrm{Aa}$ & $0.15 \pm 0.03 \mathrm{Ab}$ & $0.14 \pm 0.03 \mathrm{Ba}$ & $0.12 \pm 0.02 \mathrm{Bb}$ \\
Stomatal frequency & $15.11 \pm 3.09 \mathrm{Aa}$ & $12.95 \pm 2.03 \mathrm{Ab}$ & $10.93 \pm 3.60 \mathrm{Ba}$ & $10.72 \pm 1.92 \mathrm{Bb}$ \\
Stomatal index & $23.64 \pm 1.83 \mathrm{Aa}$ & $22.22 \pm 4.88 \mathrm{Ab}$ & $25.36 \pm 5.01 \mathrm{Aa}$ & $20.69 \pm 2.61 \mathrm{Ab}$ \\
Stomatal length* $(\mu \mathrm{m})$ & $18.45 \pm 1.95 \mathrm{Aa}$ & $18.43 \pm 1.83 \mathrm{Ab}$ & $22.21 \pm 2.92 \mathrm{Aa}$ & $15.19 \pm 1.18 \mathrm{Ab}$ \\
Stomatal width $(\mu \mathrm{m})$ & $76.87 \pm 4.65 \mathrm{Aa}$ & $70.36 \pm 10.98 \mathrm{Ab}$ & $76.74 \pm 14.08 \mathrm{Aa}$ & $71.67 \pm 4.43 \mathrm{Ab}$ \\
Stomatal area $\left(\mu \mathrm{m}^{2}\right)$ &
\end{tabular}

${ }^{1}$ Means followed by the same capital letter in seasons and lowercase in luminosities do not differ statistically from each other by the Tukey test at $5 \%$ probability level. Asterisk indicates that there is interaction between seasons and luminosities.

Table 2 - Quantitative parameters of cross-sections of Eugenia luschnathiana (O.Berg) Klotzsch ex B.D.Jacks leaves in rainy and dry seasons, as well as in the sun and shade.

\begin{tabular}{|c|c|c|c|c|}
\hline \multirow{4}{*}{ Parameters } & \multicolumn{4}{|c|}{ Season } \\
\hline & \multicolumn{2}{|c|}{ Rain } & \multicolumn{2}{|c|}{ Dry } \\
\hline & \multicolumn{2}{|c|}{ Luminosity } & \multicolumn{2}{|c|}{ Luminosity } \\
\hline & Sun & Shade & Sun & Shade \\
\hline Leaf blade* $(\mu \mathrm{m})$ & $304.78 \pm 61.52 \mathrm{Aa}$ & $230.42 \pm 6.98 \mathrm{Ab}$ & $279.94 \pm 31.286 \mathrm{Aa}$ & $258.88 \pm 17.38 \mathrm{Ab}$ \\
\hline Mesophyll* $(\mu \mathrm{m})$ & $240.60 \pm 45.43 \mathrm{Aa}$ & $182.88 \pm 15.7292 \mathrm{Ab}$ & $216.08 \pm 28.55 \mathrm{Aa}$ & $187.19 \pm 17.22 \mathrm{Ab}$ \\
\hline Adaxial cuticle $(\mu \mathrm{m})$ & $21.50 \pm 2.28 \mathrm{Aa}$ & $17.57 \pm 1.71 \mathrm{Ab}$ & $20.83 \pm 1.89 \mathrm{Ba}$ & $16.60 \pm 1.53 \mathrm{Bb}$ \\
\hline Abaxial cuticle* $(\mu \mathrm{m})$ & $11.80 \pm 4.33 \mathrm{Aa}$ & $9.14 \pm 0.89 \mathrm{Ab}$ & $10.24 \pm 2.35 \mathrm{Aa}$ & $9.87 \pm 0.95 \mathrm{Ab}$ \\
\hline Adaxial epidermis* $(\mu \mathrm{m})$ & $41.08 \pm 13.99 \mathrm{Aa}$ & $30.24 \pm 2.11 \mathrm{Ab}$ & $38.13 \pm 2.68 \mathrm{Aa}$ & $34.67 \pm 3.69 \mathrm{Ab}$ \\
\hline Epidermal abaxial* $(\mu \mathrm{m})$ & $22.76 \pm 6.39 \mathrm{Aa}$ & $16.02 \pm 1.10 \mathrm{Ab}$ & $18.59 \pm 1.77 \mathrm{Aa}$ & $16.26 \pm 2.75 \mathrm{Ab}$ \\
\hline Palisade parenchyma* $(\mu \mathrm{m})$ & $54.67 \pm 7.56 \mathrm{Aa}$ & $31.35 \pm 4.65 \mathrm{Ab}$ & $37.63 \pm 3.51 \mathrm{Ba}$ & $27.99 \pm 6.07 \mathrm{Bb}$ \\
\hline Spongy parenchyma $(\mu \mathrm{m})$ & $158.06 \pm 19.39 \mathrm{Aa}$ & $156.85 \pm 15.34 \mathrm{Ab}$ & $170.18 \pm 26.89 \mathrm{Aa}$ & $155.78 \pm 15.73 \mathrm{Ab}$ \\
\hline Length of the central vein $(\mu \mathrm{m})$ & $803.21 \pm 116.08 \mathrm{Aa}$ & $579.39 \pm 45.37 \mathrm{Ab}$ & $865.42 \pm 73.77 \mathrm{Ba}$ & $621.08 \pm 64.89 \mathrm{Bb}$ \\
\hline Width of the central vein $(\mu \mathrm{m})$ & $920.35 \pm 155.97 \mathrm{Aa}$ & $762.60 \pm 56.30 \mathrm{Ab}$ & $971.80 \pm 83.61 \mathrm{Ba}$ & $692.56 \pm 97.69 \mathrm{Bb}$ \\
\hline Area of the central vein vascular bundle* $\left(\mu \mathrm{m}^{2}\right)$ & $1977.1 \pm 474.1 \mathrm{Aa}$ & $1468.9 \pm 244.9 \mathrm{Ab}$ & $2249.9 \pm 392.5 \mathrm{Aa}$ & $1389.8 \pm 314.1 \mathrm{Ab}$ \\
\hline Amount of druses in the central vein* & $1.33 \pm 2.15 \mathrm{Aa}$ & $1.87 \pm 1.38 \mathrm{Ab}$ & $5.93 \pm 6.68 \mathrm{Ba}$ & $15.00 \pm 5.54 \mathrm{Bb}$ \\
\hline Amount of secretory cavities in the central vein & n $\quad 1.90 \pm 1.09 \mathrm{Aa}$ & $0.93 \pm 0.83 \mathrm{Ab}$ & $1.70 \pm 1.37 \mathrm{Aa}$ & $0.93 \pm 0.94 \mathrm{Ab}$ \\
\hline Length of the petiole $(\mu \mathrm{m})$ & $1487.2 \pm 210.6 \mathrm{Aa}$ & $1133.6 \pm 119.4 \mathrm{Ab}$ & $1597.3 \pm 72.8 \mathrm{Ba}$ & $1372.7 \pm 108.6 \mathrm{Bb}$ \\
\hline Width of the petiole* $(\mu \mathrm{m})$ & $1742.8 \pm 261.5 \mathrm{Aa}$ & $1416.8 \pm 45.6 \mathrm{Ab}$ & $1814.3 \pm 149.1 \mathrm{Aa}$ & $1279.8 \pm 105.9 \mathrm{Ab}$ \\
\hline Area of the petiole vascular bundle* $\left(\mu \mathrm{m}^{2}\right)$ & $2685.7 \pm 465.3 \mathrm{Aa}$ & $1961.5 \pm 230.9 \mathrm{Ab}$ & $2744.7 \pm 153.3 \mathrm{Ba}$ & $1934.2 \pm 419.1 \mathrm{Bb}$ \\
\hline Amount of druses on the petiole & $27.93 \pm 16.06 \mathrm{Aa}$ & $43.17 \pm 14.56 \mathrm{Ab}$ & $57.00 \pm 23.58 \mathrm{Ba}$ & $74.87 \pm 30.87 \mathrm{Bb}$ \\
\hline Amount of secretory cavities in the petiole* & $7.93 \pm 2.83 \mathrm{Aa}$ & $8.13 \pm 1.55 \mathrm{Ab}$ & $10.10 \pm 3.45 \mathrm{Aa}$ & $6.10 \pm 2.51 \mathrm{Ab}$ \\
\hline Area of the petiole secretory cavities $\left(\mu \mathrm{m}^{2}\right)$ & $519.73 \pm 78.66 \mathrm{Aa}$ & $361.55 \pm 42.23 \mathrm{Ab}$ & $568.59 \pm 59.43 \mathrm{Ba}$ & $422.73 \pm 25.67 \mathrm{Bb}$ \\
\hline
\end{tabular}

${ }^{1}$ Means followed by the same capital letter in seasons and lowercase in luminosities do not differ statistically from each other by the Tukey test at $5 \%$ probability level. Asterisk indicates that there is interaction between seasons and luminosities. 


\section{Conclusions}

Eugenia luschnathiana has anatomical plasticity, as it has photoaclimative capacity and responds well to seasonal variations of water availability in the Restinga region of Ceara.

Thick cuticle, hypoestomatic leaf, presence of numerous trichomes on the abaxial face and fibers in the vascular bundles are the characteristics that have been shown to be plastic to allow the acclimatization of plants to environment with intense luminosity and periods of water deficit.

\section{Acknowledgments}

To the Foundation to Support Scientific and Technological Development of Ceara (FUNCAP) for granting the Master's Degree fellowship to the first author; to the State Botanical Park of Ceara for logistic support.

\section{References}

ALMEIDA, E.I.B.; CELIN, E.F.; FREIRE, A.G.; LACERDA, C.F.; BEZERRA, M.A.; MESQUITA, R.O. Ecofisiologia de mangueiras 'Tommy Atkins' submetidas a diferentes regimes hídricos e disponibilidade de luz. Revista Agro@mbiente On-line, Boa Vista, v.9, n.3, p.251-260, 2015.

ALVARENDA, F.Q.; ROYO, V.A.; MOTA, B.F.C.; LAURENTIZ, R.S.; MENEZES, E.V.; MELO JUNIOR, A.F.; OLIVEIRA, D.A. Atividade antinociceptiva e antimicrobiana da casca do caule de Psidium Cattleyanum Sabine. Revista Brasileira de Plantas Medicinais, Campinas, v.17, n.4, p.1125-1133, 2015.

ALVARES, C.A.; STAPE, J.L.; SENTELHAS, P.C.; GONÇALVES, J.L.M.; SPAROVEK, G. Koppen's climate classification map for Brazil. Meteorologische Zeitschrift, Stuttgart, v.22, n.6, p.711-728, 2013.

AMORIM, B.S.; ALVES, M. Myrtaceae from lowland Atlantic Forest areas in the State of Pernambuco, Northeastern Brazil. Phytotaxa, Auckland, v.40, n.1, p.33-54, 2012.

AMORIM, W.; MELO JÚNIOR, J.C.F. de. Plasticidade morfoanatômica foliar de Tibouchina clavata (Melastomataceae) ocorrente em duas formações de restinga. Rodriguésia, Rio de Janeiro, v.68, n.2, p.545$555,2017$.
ARMSTRONG, L.; DUARTE, M. do R.; MIGUEL, O.G. Morpho-anatomy of the leaf and stem Eugenia pyriformis. Revista Brasileira de Farmacognosia, Curitiba, v.22, n.3, p.475-481, 2012.

BFG. Growing knowledge: an overview of seed plant diversity in Brazil. Rodriguésia, Rio de Janeiro, v.66, n.4, p.1085-1113, 2015.

BOEGER, M.R.T.; ESPÍNDOLAJÚNIOR,A.; MACCARI JÚNIOR, A.; REISSMANN, C.B.; ALVES, A.C.A.; RICKLI, F.L. Variação estrutural foliar de espécies medicinais em consórcio com erva-mate, sob diferentes intensidades luminosas. Floresta, Curitiba, v.39, n.1, p.215-225, 2009.

CARDOSO, C.M.V.; PROENÇA, S.L.; SAJO, M.G. Foliar anatomy of the subfamily Myrtoideae (Myrtaceae). Australian Journal of Botany, Darwin, v.57, n.1, p.48-161, 2009.

CASTRO, A.S.F.; MORO, M.F.; MENEZES, M.O.T. O complexo vegetacional da zona litorânea no Ceará: Pecém, São Gonçalo do Amarante. Acta Botanica Brasilica, Feira de Santana, v.26, n.1, p.108-124, 2012.

CUSTÓDIO, D.L.; KOLB, R.M.; FARIA, T. DE J.; BIANCHINI, E. Pimenta pseudocaryophyllus (Gomes) L.R. Landrum (Myrtaceae): anatomia do caule e da folha de uma planta medicinal. Semina: Ciências Biológicas e da Saúde, Londrina, v.34, n.2, p.111-124, 2013.

CUTTER, E.G. Anatomia vegetal parte I: células e tecidos. 2. ed. São Paulo: Roca, 1986. 316p.

DEFAVERI, A.C.A.; ARRUDA, R.C.O.; SATO, A. Leaf anatomy and morphology of Eugenia rotundifolia applied to the authentication of the "abajuru'" commercially sold. Revista Brasileira de Farmacognosia, Curitiba, v.21, n.3, p.373-381, 2011.

DeLUCIA, E.H.; NELSON, K.; VOGELMANN, T.C.; SMITH, W.K. Contribution of intercellular reflectance to photosynthesis in shade leaves. Plant, Celt and Environment, Illinois, v.19, n.6, p.159-170, 1996

DIAS, C.N.; RODRIGUES, K.A.F.; RESPLANDES, S.M.; AGUIAR, L. dos R.; AMARAL, F.M.M.; MORAES, D.F.C. Caracterização farmacobotânica das folhas de Eugenia uniflora L. (Myrtaceae) coletadas em São Luís - MA, BRASIL. Revista de Ciências da Saúde, São Luís, v.14, n.2, p.95-102, 2012.

DONATO, A.M.; MORRETES, B.L. Anatomia foliar de Eugenia florida DC. (Myrtaceae). Revista Brasileira de Farmacognosia, Curitiba, v.19, n.3, p.759-770, 2009. 
DONATO, A.M.; MORRETES, B.L. Morfo-anatomia foliar de Myrcia multiflora (Lam.) DC. - Myrtaceae. Revista Brasileira de Plantas Medicinais, Botucatu, v.13, n.1, p.43-51, 2011.

ESAU, K. Anatomy of seed plants. $2^{\text {nd }}$ ed. New York: John Wiley, 1977. 576p.

ESPOSITO-POLESI, N.P.; RODRIGUES, R.R.; ALMEIDA, M. Anatomia ecológica da folha de Eugenia glazioviana KIAERSK (Myrtaceae). Revista Árvore, Viçosa, MG, v.35, n.2, p.255-263, 2011.

EVERT, R.F. Anatomia das plantas de Esau: meristemas, células e tecidos do corpo da planta: sua estrutura, função e desenvolvimento. 3.ed. São Paulo: Blucher, 2013. 728p.

FERREIRA, C.S.; CARMO, W.S.; GRACIANORIBEIRO, D.; OLIVEIRA, J.M.F.; MELO, R.B.; FRANCO, A.C. Anatomia da lâmina foliar de onze espécies lenhosas dominantes nas savanas de Roraima. Acta Amazônica, Petrópoles, v.45, n.4, p.337-346, 2015 .

FRANCESCHI, V.R.; NAKATA, P.A. Calcium oxalate in plants: formation and function. Annual Review of Plant Biology, Palo Alto, v.56, p.41-71, 2005.

FRANKLIN, G.L. Preparation of thin sections of synthetic resins and wood-resin composites and a new macerating method for wood. Nature, Basingstoke, v.51, n.1, p.39$24,1945$.

FUNCEME - Fundação Cearense de Meteorologia e Recursos Hídricos. Calendário das chuvas no estado do Ceará. Fortaleza, 2018. Disponível em: $\leq$ http://www. funceme.br/app/calendario/produto/municipios/maxima/ mensal>. Acesso em: 04 jan. 2018.

GOMES, S.M.; SOMAVILLA, N.S.D.N.; GOMESBEZERRA, K.M.; MIRANDA, S. DO C. DE; CARVALHO, P.S. de; GRACIANO-RIBEIRO, D. Anatomia foliar de espécies de Myrtaceae: contribuições à taxonomia e filogenia. Revista Acta Botânica Brasílica, Belo Horizonte, v.23, n.1, p.223-238, 2009.

HIKOSAKA, K.; YASUMURA, Y.; MULLER, O.; OGUCHI, R. Resource allocation and trade-offs in carbon gain of leaves under changing environment. In: TAUSZ, M.; GRULKE, N. (Ed.). Trees in a changing environment: ecophysiology, adaptation and future survival. New York: Springer, 2014. p.1-24.
IPECE - Instituto de Pesquisa e Estratégia Econômica do Ceará. Perfil básico municipal. Caucaia, 2016. Disponível em: $\leq$ http://www.ipece.ce.gov.br/perfil basico municipal/2016/Caucaia.pdf $>$. Acesso em: $0 \overline{4}$ jan. 2018.

JENSEN, W.A. Botanical histochemistry: principles and pratices. São Francisco: W. H. Freeman, 1962. 408p.

JOHANSEN, D.A. Plant microtechnique. New York: McGraw Hill, 1940. 523p.

KARABOURNIOTISA, G.; BORNMANB, J.F. Penetration of UV-A, UV-B and blue light through the leaf trichome layers of two xeromorphic plants, olive and oak, measured by optical fibre microprobes. Physiologia Plantarum, Sweden, v.105, n.4, p.655-661, 1999.

KRAUS, J.E., ARDUIN, M. Manual básico de métodos em morfologia vegetal. Rio de Janeiro: Editora da Universidade Federal Rural do Rio de Janeiro, 1997. $198 \mathrm{p}$.

LARCHER, L.; BOEGER, M.R.T. Arquitetura foliar de Odontonema strictum (Nees) O. Kuntze (Acanthaceae) em duas condições de luminosidade. Hoehnea, São Paulo, v.36, n.2, p.321-327, 2009.

LARCHER, W. Ecofisiologia vegetal. 2. ed. São Carlos: Rima, 2001. 531p.

LOURENÇO, A.R.L.; BARBOSA, M.R.V. Myrtaceae em restingas no limite norte de distribuição da Mata Atlântica, Brasil. Rodriguésia, Rio de Janeiro, v.63, n.2, p.373-393, 2012.

LUCENA, E.M.P. de; ALVES, R.E.; CISNEROSZEVALLOS, L.; MORAES LUZ, E.W.; BRITO, E.S. Biodiversidade das Myrtaceae brasileiras adaptadas à Flórida, EUA. Revista Brasileira de Geografia Física, Recife, v.7, n.2, p.327-340, 2014.

LUQUE, R.; SOUSA, H.C.; KRAUS, J.E. Métodos de coloração de Roeser (1972) - modificado - e Kropp visando a substituição do azul de astra por azul de alcião GS ou GX. Acta Botânica Brasílica, Belo Horizonte, v.10, n.2, p.199-212, 1996.

MENEZES, N.L.; SILVA, D.C.; PINNA, G.F.A.M. Folha. In: APEZZATO-DA-GLÓRIA, B.; CARMELLOGUERREIRO, S.M. Anatomia vegetal. 2.ed. Viçosa: UFV, 2006. cap.12, p.303-326. 
METCALFE, C.R.; CHALK, L. Anatomy of the dicotyledons: systematic anatomy of the leafand stem. $2^{\text {nd }} e d$. Claredon: Oxford University Press, 1979. v.1, 288 p.

MORALES, F.; ABADÍA, A.; ABADÍA, J. MONTSERRAT, G.; GIL-PELEGRÍN, E. Trichomes and photosynthetic pigment composition changes: responses of Quercus ilex subsp. ballota (Desf.) Samp. and Quercus coccifera L. to Mediterranean stress conditions. Trees, Manchester, v.16, n.1, p.504-510, 2002.

MULLER, C.; RIEDERER, M. Plant surface properties in chemical ecology. Journal of Chemical Ecology, Morehead, v.31, n.11, p.2621-2651, 2005.

NIINEMETS, U. Photosynthesis and resource distribution through plant canopies. Plant, Cell \& Environment, Wiley, v.30, n.9, p.1052-1071, 2007.

O'CARRIGANA, A.; HINDEB, E.; LUA, N.; XUA, X.; DUANC, H.; HUANGC, G.; MAKA, M.; BELLOTTI, B.; CHENA, Z. Effects of light irradiance on stomatal regulation and growth of tomato. Environmental and Experimental Botany, Oxford, v.98, n.2, p.65- 73, 2014.

OGUCHI, O.; HIKOSAKA, K.; HIURA, T.; HIROSE, T. Leaf anatomy and light acclimation in woody seedlings after gap formation in a cool-temperate deciduous forest. Oecologia, Berlin, v.149, n.1, p.571-582, 2006.

OLIVEIRA, E.C.; MIGLIORANZA, É.; ALMEIDA, L.H.C. Frequência estomática entre cultivares de mandioca avaliada por gráficos de caixa. Agropecuária Científica no Semiárido, Campina Grande, v.12, n.2, p.230-236, 2016a.

OLIVEIRA, J.D.; ALVES, C.C.F.; MIRANDA, M.L.D.; MARTINS, C.H.G.; SILVA, T.S.;AMBROSIO, M.A.L.V.; ALVES, J.M.; SILVA, J.P. Rendimento, composição química e atividades antimicrobiana e antioxidante do óleo essencial de folhas de Campomanesia adamantium submetidas a diferentes métodos de secagem. Revista Brasileira de Plantas Medicinais, Campinas, v.18, n.2, p.502-510, 2016b.

PACHECO-SILVA, N.V.; DONATO, A.M. Morphoanatomy of the leaf of Myrciaria glomerata. Revista Brasileira de Farmacognosia, Curitiba, v. 26, n.1, p.275280, 2016.
PAIVA, J.G.A.; FANK-de-CARVALHO, S.M.; MAGALHÃES, M.P.; GRACIANO-RIBEIRO, D. Verniz vitral incolor 500: uma alternativa de meio de montagem economicamente viável. Acta Botânica Brasílica, Belo Horizonte, v.20, n.2, p.257-264, 2006.

RABELO, G.R.; VITÓRIA, A.P.; SILVA, M.V.A.; CRUZ, R.A.; PINHO, E.I.B.; RIBEIRO, D.R.; FREITAS, A.V.; CUNHA, M. Structural and ecophysiological adaptations to forest gaps. Trees, Manchester, v.27, n.1, p.259-272, 2013.

RETAMALES,H.A.;SCHERSON, R.; SCHARASCHKIN, T. Foliar micromorphology and anatomy of Ugni molinae Turcz. (Myrtaceae), with particular reference to schizogenous secretory cavities. Revista Chilena de Historia Natural, Santiago, v.87, n.27, p.1-7, 2014.

REYNERTSON, K.A.; YANG, H.; JIANG, B.; BASILE, M.J.; KENNELLY, E.J. Quantitative analysis of antiradical phenolic constituents from fourteen edible Myrtaceae fruits. Food Chemistry, Norwich, v.109, n.4, p.883-890, 2008.

SÁ, R.D.; SANTANA, A.S.C.O.; RANDAU, K.P. Caracterização anatômica e histoquímica das folhas de Eugenia uniflora L. Journal of Environmental Analysis and Progress, Recife, v.1, n.1, p 96-105, 2016.

SANTOS, J.W.; ALMEIDA, F.A.C.; BELTRÃO, N.E.M.; CAVALCANTI, F.B. Estatística experimental aplicada. 2.ed. Campina Grande: Embrapa Algodão/UFCG, 2008. $461 \mathrm{p}$.

SATO, Y.; KUDOH, H. Fine-scale frequency differentiation along a herbivory gradiente in the trichome dimorphism of a wild Arabidopsis. Ecology and Evolution, Nueremberg, v.7, n.1, p.2133-2141, 2017.

SCHOCH, P.; ZINSOU, C.; SIBI, M. Dependence of the stomatal index on environmental factors during stomatal differentiation in leaves of Vigna sinensis L. Journal of Experimental Botany, Oxford, v.31, n.124, p.1211-1216, 1980.

SILVA, I.V.; NOBERTO-IRMÃO, V.; LAROCCA, D.G.; ROSSI, A.A.B.; DARDENGO, J.F.E. Contribuição ao estudo farmacobotânico de Myciaria trunciflora Berg (Myrtaceae). Enciclopédia Biosfera, Goiânia, v.9, n.17, p.2746-2760, 2013.

SILVA, L.M.; ALQUINI, Y.; CAVALLET, V.J. Interrelações entre a anatomia vegetal e a produção vegetal. Acta Botânica Brasílica, Belo Horizonte, v.19, n.1, p.183-194, 2005. 
SIMIONI, P.F.; EISENLOHR, P.V.; PESSOA, M.J.G.; SILVA, I.V. Elucidating adaptive strategies from leaf anatomy: Do Amazonian savannas present xeromorphic characteristics? Flora: Morphology, Distribution, Functional Ecology of Plants, Freiberg, v.226, n.1, p.38-46, 2017.

SIMONETTI, E.; ETHUR, M.E.; CASTRO, L.C.; KAUFFMANN, C.; GIACOMIN, A.C.; LEDUR, A.; AROSSI, K.; PACHECO, L.A.; GOETTERT, M.I.; FALEIRO, D.; FREITAS, E.M. Avaliação da atividade antimicrobiana de extratos de Eugenia anomala e Psidium salutare (Myrtaceae) frente à Escherichia coli e Listeria monocytogenes. Revista Brasileira de Plantas Medicinais, Campinas, v.18, n.1, p.9-18, 2016.

SULTAN, S.E. Phenotypic plasticity for plant development, function and life history. Trends in Plant Science, Middletown, v.5, n.12, p.537-542, 2000.

SULTAN, S.E. Phenotypic plasticity in plants: a case study in ecological development. Evolution \& Development, Malden, v.5, n.1, p.25-33, 2003.

SUTCLIFFE, J.F. As plantas e a água. São Paulo: EPU/ EDUSP, 1980. 126 p.
TAIZ, L.; ZEIGER, E. Fisiologia vegetal. 5.ed. Porto Alegre: Artmed, 2013. 954p.

VALLADARES, F.; WRIGHT, S.J.; LASSO, E.; KITAJIMA, K.; PEARCY, R.W. Plastic phenotypic response to light of 16 congeneric shrubs from a panamanian rainforest. Ecology, Washington, v.81, n.7, p.1925-1936, 2000.

VIEIRA, S. Introdução à bioestatística. 4.ed. Rio de Janeiro: Elsevier, 2011. 360p.

VILE, D.; PERVENT, M.; BELLUAU, M.; VASSEUR, F.; BRESSON, J.; MULLER, B.; GRANIER, C.; SIMONNEAU, T. Arabidopsis growth under prolonged high temperature and water deficit: independent or interactive effects? Plant, Cell and Environment, Oxford, v.35, n.1, p.702-718, 2012.

VOGELMANN, T.C.; MARTIN, G. The functional significance of palisade tissue: penetration of directional versus diffuse light. Plant, Cell and Environment, Oxford, v.16, n.1, p.65-72, 1993.

WILLMER, C.; FRICKER, M. Stomata. $2^{\text {nd }}$ ed. Londres: Chapman \& Hall, 1996. 392p. 